\title{
A Case Study of Milk Processing Plant of Parag Dairy Faizabad
}

\section{Rakesh B. Gautam*, Raj Mani Maurya, Ramjeet Singh Sangam Ram, Satish kumar Verma, Sandeep Agrahari, Sudheer Kumar, Sri Prakash Maurya and Atul Kumar Verma}

Dept. of Agro-Processing and Rural Industries, Mahamaya College of Agricultural Engineering \& Technology, NDUAT, Kumarganj, Faizabad, U.P. (224 122), India

\section{Corresponding Author}

Rakesh B. Gautam

e-mail: rksh_gautam@yahoo.co.in

\author{
Article History \\ Article ID: AR1857a \\ Received in $08^{\text {th }}$ December, 2017 \\ Received in revised form $17^{\text {th }}$ September, 2018 \\ Accepted in final form $20^{\text {th }}$ September, 2018
}

\begin{abstract}
India is endowed with a largest livestock population in the world having a total bovine population of 304 million compared to the world total bovine population of 1400 million. There has been a major improvement in milk production, which increased from $17 \mathrm{mt}$ in 1951 to $127.9 \mathrm{mt}$ during 2011-12. Per capita availability of the milk has reached a level of $290 \mathrm{~g}^{2} \mathrm{yy}^{-1}$ during the year 2011-12, which more than the world average of $284 \mathrm{~g}_{\text {day }}{ }^{-1}$. Most of the milk in the country is produced by small, marginal farmers and landless laborers. In order to increase milk production, the government has approved national dairy plan phase-1 (NDP-1) in February, 2012 with a total investment of about ₹ 2242 core to be implemented from 2011-12 to 2016-17. Department of animal husbandry, dairying and fisheries, ministry of agricultural Government of India is also implementing "national program on bovine breeding and dairy development (NPBBDD) from 2013-14 to 2016-17 through the state implementing agencies/end implementing agencies/participating agencies. The organized dairy sector (both cooperative and private) is presently handling about $15 \%$ of the total milk production in the country. Dairy products form one of the fastest growing segments in livestock product export. India's export of dairy product was $25928.52 \mathrm{mt}$ to the world for the worth of $₹ 4318.53$ cores during the year 2015-16.
\end{abstract}

Keywords: Milk, milk product, production, livestock, dahi, khoya and cheese

\section{Introduction}

India is endowed with a largest livestock population in the world having a total bovine population of 304 million compared to the world total bovine population of 1400 million. It account for $56.3 \%$ of the world's buffalo population and $14.7 \%$ of the cattle population. As per $18^{\text {th }}$ livestock census, 2007 the country has 33.06 million cross breed cattle, 199.07 million indigenous cattle and 105.34 million buffaloes. (Srivastava, Singh and Mohan, 2008). The cross breed cattle are predominant in Tamil Nadu, Maharashtra, West Bengal, Karnataka, Andhra Pradesh, Uttar Pradesh, Madhya Pradesh, Gujarat, Punjab, Haryana, and Bihar. There has been a major improvement in milk production, which increased from 17 million tones in 1951 to $127.9 \mathrm{mt}$ during 2011-12. Uttar Pradesh, Punjab, Madhya Pradesh, Haryana, Rajasthan, Gujarat, Bihar, Maharashtra, Andhra Pradesh and Tamil Nadu contribute to the extent of $80 \%$ of the total milk production in India. Per capita availability of the milk has reached a level of 290 grams per day during the year 2011-12, which more than the world average of $284 \mathrm{~g} \mathrm{day}^{-1}$. Most of the milk in the country is produced by small, marginal farmers and landless laborers (Anonymous, 2017).

Recognizing the importance of the sector, several key initiatives were taken by the govt. In the past ranging from operation flood program, intensive dairy development program (IDDP), strengthening infrastructure for clean milk production, assistant to cooperatives, venture capital fund (VCF) for dairy, dairy entrepreneurship development scheme etc.

In order to meet the rapidly growing demand for milk with a focus to improve Milch animal productivity and increase milk production, the government has approved national dairy plan phase-1 (NDP-1) in February, 2012 (Padhi, 2014). with a total investment of about ₹ 2242 core to be implemented from 2011-12 to 2016-17. NDP-1 will help to meet the projected national demand of 150 million tons of milk by 2016-17 from domestic production through productivity enhancement, strengthening and expanding village level infrastructure for milk procurement and provide producer with greater access to markets. NDP-1 would focus on 14 major milk producing states- Uttar Pradesh, Punjab, Haryana, Gujarat, Rajasthan, Madhya Pradesh, Bihar, west Bengal, Maharashtra, Karnataka, 
Tamil Nadu, Andhra Pradesh, Orissa, and Kerala which account over $90 \%$ of the country's milk production. Coverage of NDF1 will however be across the country in terms of benefits accruing from the scheme.

Department of animal husbandry, dairying \& fisheries, ministry of agricultural Government of India is also implementing "national program on bovine breeding and dairy development (NPBBDD) from 2013-14 to 2016-17 through the state implementing agencies/ end implementing agencies/ participating agencies.

The organized dairy sector (both cooperative and private) is presently handling about $15 \%$ of the total milk production in the country. Thus it indicates, there is a wide scope for processing of milk and manufacture of milk products for domestic consumption as well as export.

Dairy products form one of the fastest growing segments in livestock product export. India's export of dairy product was $25928.52 \mathrm{mt}$ to the world for the worth of ₹ 4318.53 cores during the year 2015-16. The major export destinations are Bangladesh, Egypt, UAE, Algeria, Yemen Republic, Pakistan, Saudi Arabia and Malaysia. The major products exported were butter and other milk fat, cheese, whole milk powder, skimmed milk powder, fresh cream, ghee, butter milk etc.

\section{Materials and Methods}

\subsection{Raw material}

The principle raw material is milk. The extent of milk procurement area milch animal population, average milk yield, percentage of animals in milk, marketed surplus etc will determine the size of the plant. The method of procurement, transportation of milk and input supply to the farmers is required to be highlighted. The availability of other inputs such as packing materials, disinfectants and consumables should be ascertained.

\subsection{Layout and buildings}

The civil works comprise of main processing building, which include raw milk reception dock. Main processing hall, provision for manufacture of other products, cold storage, CIP, laboratory, Quarters, office, garages, security post etc. The factory building for the milk reception, quality control, processing, packaging and storage of milk products should be as per BIS specification, the quantity of milk handled and the equipment chosen product manufacturing. About $4000 \mathrm{sq}$. Ft, area of building is required for handling 10000 I of milk. The essential section of milk processing plants is given in below.

The milk processing plant shall have the following essential facilities.

\subsubsection{Raw milk reception dock (RMRD)}

consisting of can conveyor, can washer, weighing balance, dump tank etc.

Processing hall: cream separator, chiller, homogenizer, pasteurizer and other related machinery are installed. Storage area: For milk storage tanks.
Products manufacturing area: depends upon the type of products, quantity of milk handled and the machinery to be installed.

Packaging area: For packing of liquid milk and other products. Cold storage: For keeping the milk and milk products before sending of market.

Quality control laboratory: For testing the quality of milk and milk products.

Utilities area: For installing boiler, generator set, water treatment plants, maintenance and store area for spares.

Waste water treatment plant area: For treating the dairy effluents before releasing to the fields.

Quarters and office area: for all the essential staff.

Vehicle parking area: Both for the milk procurement and distribution vehicles.

Input supply area: for providing veterinary service, supply of feed, fodder seed, etc

\subsection{Plant and Machinery}

Different machinery are required for the processing plant based on the type of milk received and products proposed. The machinery should be as per the BIS specifications. The section wise equipment required, their specifications and quantity for 10000 liters capacity milk processing plant are given below (Table 1).

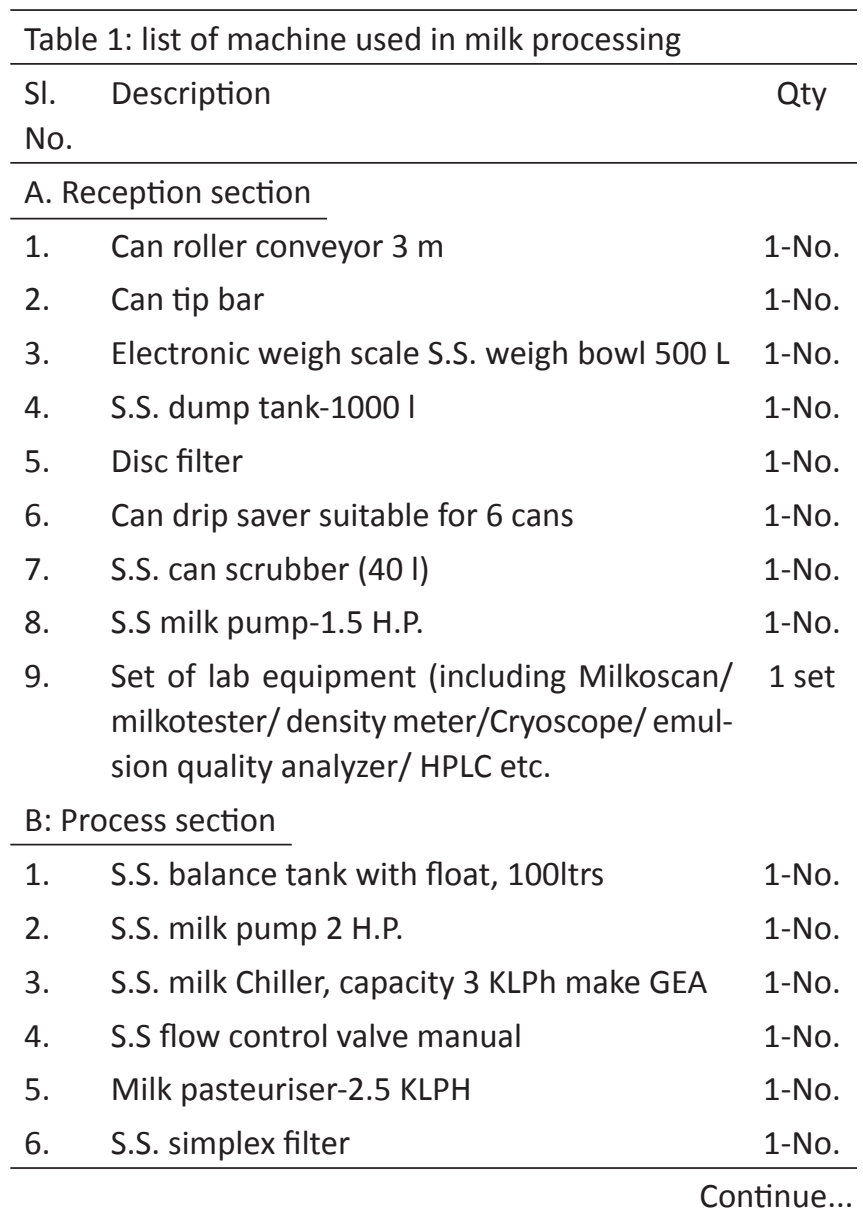




\begin{tabular}{|c|c|c|}
\hline $\begin{array}{l}\text { Sl. } \\
\text { No. }\end{array}$ & Description & Qty \\
\hline 7. & S.S. holding coil for 16 secs & 1-No. \\
\hline 8. & Flow diversion valve manual & 1-No. \\
\hline 9. & S.S. remote control panel & 1-No. \\
\hline 10. & Inter connecting S.S. pipeline and valves & 1 set \\
\hline 11. & Cream separator capacity 500 Itrs par hour & 1-No. \\
\hline 12. & Cream tank $-1 \mathrm{KL}$ & 1-No. \\
\hline 13. & Ghee boiler-250Ltrs & 1-No. \\
\hline 14. & Ghee balance tank and pump & 1-set \\
\hline 15. & Gee settling tank $-250 \mathrm{lt}$ & 1-No. \\
\hline 16. & CIP unit & 1-set \\
\hline \multicolumn{3}{|c|}{ C. Storage and packing section } \\
\hline 1. & H.M.S.T-M.S Outer 5KL, single comp. & 1-No. \\
\hline 2. & H.MS.T-M.S. Outer 10KL, double comp. & 1-No. \\
\hline 3. & S.S. milk pump-1H.P. & 1-No. \\
\hline 4. & Pouch packing machine, $5000 \mathrm{PPH}$ & 2-No. \\
\hline 5. & S.S. overhead tank capacity 200ltrs.(INSU) & 1-No. \\
\hline 6. & Interconnecting SS pipe and valves & 1-set \\
\hline 7. & Spare S.S. pump for tanker filling & 1-No. \\
\hline 8. & G.I pipeline and controls, driers for air & 1-set \\
\hline & Stabilizer for packing machine & 1-No. \\
\hline D. $R$ & frigeration section & 1-set \\
\hline
\end{tabular}

1. How water generator capacity $50000 \mathrm{kcal} \mathrm{Hr}$. 1-No. Wood fired

2 Chimney 3mt high above

1-No.

3. Makeup water tank and valves.( FRP- 200ltr) 1-No.

4. Water softener suitable duty 1-No.

5. G.I pipeline, valves and water pump 1-No.

F. Electricals

$1 \quad$ MCCB panel for above equipments

2. All cables armoured, flexible, and other 1-set

3. Generator 3 KVA

G. Erection and commissioning

\subsection{Pasteurization}

Pasteurization is the first step in milk processing. Pasteurization means heating every particle of the milk or milk product to a specific temperature for a specified period of time $\left(63^{\circ} \mathrm{C}\right.$ for 30 minutes). This destroys bacteria and other micro-organism that may affect consumer health. It makes the milk safe and healthy, and also improves the keeping quality. So that milk and milk products can be stored for longer periods without being spoilt.

\subsubsection{Method of pasteurization}

1. Batch pasteurization: $63^{\circ} \mathrm{C}$ for at least 30 minutes. This is suitable for small-scale producers and farmer cooperatives.

2. High temperature short time (HTST) pasteurization: $72{ }^{\circ} \mathrm{C}$ for at least 15 minutes. This is suitable for processing large quantities of milk. E.g. more than 250 liters at a time.

3. Ultra high temperature (UHT): $135{ }^{\circ} \mathrm{C}$ this is used by big factories. It requires special machinery. UHT milk can be stored for 6 month even without refrigeration.

\subsection{Data and methodology}

An ISO-9002 dairy plant installed capacity of 60000 liter per day situated in Uttar Pradesh state, Faizabad dairy was selected for the study. The data for the period OctoberNovember 2016 on various aspect works collected from the records of the dairy plant, by interviewing the personal working in the plant and by observation method. During the study period the dairy plant manufactured Ghee, ice cream, fully cream milk, standardized milk, toned milk, double toned milk and skimmed milk.

For working out the economics of manufacturing of different Dairy products, the plant under study was classified into two departments namely Main departments and Auxiliary department (Raju, G. Rama Mohan, 1980). The farmer was directly related to the manufacturing of dairy products, where-as the later provided service like steam generation, refrigeration, water supply, maintenance quality control etc.

Cost on services provided by the Auxiliary department work apportioned to the main department by using the appropriate burden rates. Depreciation of the building/equipment was worked out by straight-line method. While allocating and apportioning the expenses, due care was take into identify the fix and variable cost items for break-even analysis.

The break even quantity, steam requirement, electrical energy and refrigeration requirement were worked out as discussed below.

\subsubsection{Break-even output}

$\mathrm{TR}=\mathrm{TC}$

$P \times Q=T F C+(A \vee C \times Q)$.

$(P \times Q)-(A \vee C \times Q)=T F C$.

$(P-A V C) Q=T F C$

$\mathrm{Q}=\mathrm{TFC} /(\mathrm{P}-\mathrm{AVC})$

Where,

$T R=$ Total revenue

TC=Total cast

$\mathrm{P}=$ Price of product

$Q=$ Break even output

TFC=Total fixed cost

$\mathrm{AVC}=$ Average variable cost

\subsubsection{Steam requirement}

Steam requirement $(\mathrm{kg})=(\mathrm{MST}) / \mathrm{L}$ 
Where,

$M=$ Quantity of product to be heated

$\mathrm{S}=$ Specific heat

$\mathrm{T}=$ Temperature difference

$\mathrm{L}=$ Latent heat

\subsubsection{Electrical consumption}

Electrical consumption $=($ hours watts) $/ 1000=K W$

Electricity under single phase system $=\left(V_{L} \times I_{L} \times \cos \theta\right) / 1000=K W$

Electricity consumption was computed using the formula (Theraja, 1992)

$\left(\mathrm{V} 3 \times \mathrm{V}_{\mathrm{L}} \times \mathrm{I}_{\mathrm{L}} \times \cos \varnothing\right) / 1000=\mathrm{KW}$

Where,

$\mathrm{V}_{\mathrm{L}}=$ line voltage

$I_{L}=$ line current

$\cos \theta=$ Power factor

\subsubsection{Refrigeration requirement}

Refrigeration load $=\mathrm{M} \times \mathrm{S} \times \mathrm{T}$ (in kcal)

Where,

$M=$ Quantity of product to be cooled

$\mathrm{S}=$ Specific heat

$\mathrm{T}=$ Temperature difference

\subsection{Components of milk}

Milk contains many different components like water, fat, protein, lactose, and ash. The most important components is butterfat, which gives milk its special creamy taste and colour. Butterfat is used to make many different products such as cream, butter, butter oil, and ghee. The amount of butterfat in milk depends on species (cow, goat etc) and the breed. Goat milk contains 3 to $5.6 \%$ butterfat. Cow milk contains 3.2 to $5.5 \%$.sheep milk contains 6.4 to $9 \%$

\subsection{Milk storage}

The plant will need bulk storage tanks for milk and milk products of a total capacity approximately equal to the daily through output. The calculation requirements of storage capacity are rate and time at which the contents will be used and the time required for cleaning before re-use. It is usually advisable to make provision for alternative usage for each tank. It will help in the later stages of planning if the number of different size is kept to the minimum.

It is helpful in planning to prepare a tank utilization schedule. This schedule is based on assumption regarding the rates of milk reception and utilization.

\subsection{Cream separation}

Cream separators may be required for standardizing the fat content of milk before processing for liquid consumption, and for producing cream for butter making. The number and capacity of the separator required depends on the average fat content of the incoming milk and the amount of cream required. (Bourton $H ., 1988$ ) As in the case of clarifiers, duplicate or stand by machine or necessary in case of breakdown.

\subsection{Heat treatment}

Where the rate of processing is less than about 1000 hour $^{-1}$ Batch treatment is usually adopted. For higher rates HTST method are necessary in order to keep the flow space required within reasonable limit and to improve efficiency by regenerative heating and cooling. If the HTST plant is required to run for longer period, cleaning will be necessary after about 5 hours operation. To prevent the accumulation of deposit on the heating surface and to control Thermophilic bacteria (Ahmed Tufail, 1997). Milk of different qualities or for different purpose can be treated successively in the same machine.

\subsection{Butter manufacture}

Butter is obtained from cream. In butter making the oil in water emulsion of cream is converted by the process of churning into the water-in-emulsion of butter.

\subsection{Cheese manufacture}

The manufacture of cheese has become a major activity in many dairy processing plants. Cheese made from the curd obtained from whole milk or skim milk. The coagulation may be effected either by acid or enzyme. Most of the protein and fat is retained by cheese. Cheese can be divided into lactic cheese and rennet cheese (Alganesh, 2002 ).

\subsection{Ice cream}

Ice cream can be made on either a batch or a continuous basis, depending on the scale of production. Demand of ice cream is seasonal and liable to great fluctuation. It is necessary therefore to have the maximum flexibility of production and to make provision for storage.

\section{Results and Discussion}

The process-wise costs for different products were calculated by dividing the manufacturing costs of product into different major process in consultation with the production manager of the plant (Glover, 1986). The information is presented under below under different sub-sections.

\subsection{Process-wise costs of milk and milk products}

The process-wise costs worked out for different dairy products are presented below for each product manufactured during the study period.

\subsubsection{Ghee}

Ghee was manufactured by direct boiling of cream and was packaged after settling and clarification. The cost of ghee manufacturing worked out to be $₹ 120.97 \mathrm{~kg}^{-1}$ the maximum cost $(94.01 \%)$ was shared by the raw material. Out of the five processes of Ghee manufacturing, the highest cost was on 'packaging' (3.60\%), followed by boiling of cream, $(0.89 \%)$, settling and clarification $(0.74 \%)$, storage $(0.63 \%)$ and reception of cream $(0.13 \%)$ (Table 2$)$.

\subsection{Processing of milk}

The process-wise costs of full-cream milk, standardized milk, 


\begin{tabular}{lccc}
\hline \multicolumn{5}{l}{ Table 2: Process-wise cost of Ghee manufacturing; } & 2015-16 \\
\hline Items & $\begin{array}{c}\text { Total annual } \\
\text { expenditure (₹) }\end{array}$ & $\begin{array}{c}\text { Unit cost } \\
\left(₹ \mathrm{~kg}^{-1}\right)\end{array}$ & $\begin{array}{c}\text { Costs } \\
\text { (\%) }\end{array}$ \\
\hline Raw material & 9607748 & 113.72 & 94.01 \\
Reception of cost & 13705 & 0.16 & 0.13 \\
Boiling of cream & 91386 & 1.08 & 0.89 \\
Settling and & 75415 & 0.89 & 0.74 \\
clarification & & & \\
Packaging & 367622 & 4.36 & 3.60 \\
Storage & 63950 & 0.76 & 0.63 \\
Overall & 10219826 & 120.97 & 100 \\
Total quantities & $84486 \mathrm{~kg}^{-1}$ & & \\
produced & annum & & \\
\hline
\end{tabular}

toned milk, double toned milk and skimmed milk have been presented below the table.

\subsubsection{Full-cream milk}

The costs of manufacturing worked out to be ₹ $14.69 \mathrm{I}^{-1}$, of which $(91.98 \%)$ was on raw material. In different process of manufacturing the highest cost was on packaging $(3.33 \%)$, followed by pasteurization/standardization (1.53\%), separation (1.31\%), storage(1.16\%) and reception of milk $0.63 \%$ (Table 3).

Table 3: Process-wise costs of Full cream milk manufacturing, 2015-16

\begin{tabular}{lccc}
\hline Items & $\begin{array}{c}\text { Total annual } \\
\text { expenditure (₹) }\end{array}$ & $\begin{array}{c}\text { Unit cost } \\
\left(₹ \mathrm{~kg}^{-1}\right)\end{array}$ & $\begin{array}{c}\text { Costs } \\
(\%)\end{array}$ \\
\hline Raw material & 135813208 & 13.51 & 91.98 \\
Reception of milk & 1005427 & 0.10 & 0.63 \\
Separation & 1942520 & 0.19 & 1.31 \\
Pasteurization/stan- & 2265138 & 0.23 & 1.53 \\
dardization & & & \\
Packaging & 4919948 & 0.49 & 3.33 \\
Storage & 1711191 & 0.17 & 1.16 \\
Overall & 147657432 & 14.69 & 100 \\
\hline
\end{tabular}

\subsubsection{Standardized milk}

Its manufacturing cost worked out to be ₹ $12.66 \mathrm{I}^{-1}$ with major cost on raw material (91.79\%). In process of manufacturing the higher cost was on packaging (3.55\%), followed by pasteurization/standardization (1.34\%), storage (1.19\%) and reception $(0.71 \%)$ (Table 4$)$.

\subsubsection{Toned milk}

Its manufacturing cost was found as $₹ 10.85 \mathrm{I}^{-1}$ with maximum raw material. Different process of manufacturing the highest cost was on packaging (3.78\%) followed by separation (1.38\%), pasteurization/standardization (1.29\%), storage (1.29\%) and reception of milk (0.64\%) (Table 5$)$.
Table 4: Process-wise costs of Standardized milk manufacturing, 2015-16

\begin{tabular}{lccc}
\hline Items & $\begin{array}{c}\text { Total annual } \\
\text { expenditure }(₹)\end{array}$ & $\begin{array}{c}\text { Unit cost } \\
\left(₹ \mathrm{~kg}^{-1}\right)\end{array}$ & $\begin{array}{c}\text { Costs } \\
(\%)\end{array}$ \\
\hline Raw material & 16353965 & 11.62 & 91.79 \\
Reception of milk & 126665 & 0.09 & 0.71 \\
Separation & 253331 & 0.18 & 1.42 \\
$\begin{array}{l}\text { Pasteurization/stan- } \\
\text { dardization }\end{array}$ & 239257 & 0.17 & 1.34 \\
$\begin{array}{l}\text { Packaging } \\
\text { Storage }\end{array}$ & 633329 & 0.45 & 3.55 \\
$\begin{array}{l}\text { Overall } \\
\begin{array}{l}\text { Total quantity pro- } \\
\text { duced }\end{array}\end{array}$ & $\begin{array}{c}1781109 \\
\text { annum }\end{array}$ & 0.15 & 1.19 \\
\hline
\end{tabular}

Table 5: Process-wise costs of Toned milk manufacturing, 2015-16

\begin{tabular}{lccc}
\hline Items & $\begin{array}{c}\text { Total annual } \\
\text { expenditure }(₹)\end{array}$ & $\begin{array}{c}\text { Unit cost } \\
\left(₹ \mathrm{~kg}^{-1}\right)\end{array}$ & $\begin{array}{c}\text { Costs } \\
(\%)\end{array}$ \\
\hline Raw material & 31293973 & 9.94 & 91.62 \\
Reception of milk & 220380 & 0.07 & 0.64 \\
Separation & 472243 & 0.15 & 1.38 \\
$\begin{array}{l}\text { Pasteurization/stan- } \\
\text { dardization }\end{array}$ & 440760 & 0.14 & 1.29 \\
$\begin{array}{l}\text { Packaging } \\
\text { Storage }\end{array}$ & 1290798 & 0.41 & 3.78 \\
$\begin{array}{l}\text { Overall } \\
\begin{array}{l}\text { Total quantity pro- } \\
\text { duced }\end{array}\end{array}$ & $\begin{array}{c}34150760 \\
\text { annum }\end{array}$ & 0.14 & 1.29 \\
\hline
\end{tabular}

\subsubsection{Double toned milk}

Its manufacturing cost worked out to be ₹ $9.46 \mathrm{I}^{-1}$ with maximum on raw material (91.12\%). In manufacturing the highest cost was on packaging, followed by pasteurization/ standardization, storage, separation, reception of milk (Table $6)$.

\subsubsection{Skimmed milk}

Its manufacturing cost was found as $₹ 7.27 \mathrm{I}^{-1}$ with maximum on raw material. Amongst process of manufacturing the highest cost was on packaging followed by storage, pasteurization/standardization, separation, reception of milk (Table 7).

\subsection{Profit margins of different dairy products}

The highest profit margin was in ice-cream followed by ghee. Amongst different types of milk, standardized milk provided the maximum profit, followed by the full cream milk and toned milk (Figure 1). 


\begin{tabular}{lccc}
\hline \multicolumn{4}{l}{$\begin{array}{l}\text { Table 6: Process-wise costs of Double toned milk } \\
\text { manufacturing, 2015-16 }\end{array}$} \\
\hline Items & $\begin{array}{c}\text { Total annual } \\
\text { expenditure (₹) }\end{array}$ & $\begin{array}{c}\text { Unit cost } \\
\left(\text { ( kg }^{-1}\right)\end{array}$ & $\begin{array}{c}\text { Costs } \\
(\%)\end{array}$ \\
\hline Raw material & 170562699 & 8.62 & 91.12 \\
Reception of milk & 1187211 & 0.06 & 0.64 \\
Separation & 2374423 & 0.12 & 1.27 \\
Pasteurization/stan- & 2572291 & 0.13 & 1.37 \\
dardization & & & \\
Packaging & 7914742 & 0.40 & 4.23 \\
Storage & 2572291 & 0.13 & 1.37 \\
Overall & 187183658 & 9.46 & 100 \\
Total quantity pro- & 19786856 I & & \\
duced & annum & & \\
\hline
\end{tabular}

Table 7: Process-wise costs of Skimmed milk manufacturing, 2015-16

\begin{tabular}{lccc}
\hline Items & $\begin{array}{c}\text { Total annual } \\
\text { expenditure }(₹)\end{array}$ & $\begin{array}{c}\text { Unit cost } \\
\left(₹ \mathrm{~kg}^{-1}\right)\end{array}$ & $\begin{array}{c}\text { Costs } \\
(\%)\end{array}$ \\
\hline Raw material & 3211539 & 6.51 & 89.54 \\
Reception of milk & 24666 & 0.05 & 0.69 \\
$\begin{array}{l}\text { Separation } \\
\text { Pasteurization/ }\end{array}$ & 49332 & 0.10 & 1.38 \\
standardization & 54266 & 0.11 & 1.51 \\
Packaging & 187463 & 0.38 & 5.23 \\
Storage & 59199 & 0.12 & 1.65 \\
Overall & 3586465 & 7.27 & 100 \\
Total quantity & 493324 I & & \\
produced & annum & & \\
\hline
\end{tabular}

\subsection{Net profit of milk processing of different products}

The cost of ghee manufacturing worked out to be ₹ 120.97 $\mathrm{kg}^{-1}$. The maximum cost $(94.01 \%)$ was shared by the raw material and the actual selling price of the ghee is ₹ 390.00 $\mathrm{kg}^{-1}$, so the profit in processing of ghee is ₹ 269.03 . The costs of Skimmed milk manufacturing worked out to be ₹ 14.69 $\mathrm{I}^{-1}$, of which (91.98\%) was on raw material and the actual selling price of Skimmed milk is ₹ $30.00 \mathrm{I}^{-1}$, so the profit in this product is ₹ 15.31 . The manufacturing cost of toned milk was found as ₹ $10.85 \mathrm{I}^{-1}$ with maximum raw material and the selling price of toned milk is ₹ $38 \mathrm{I}^{-1}$, so the profit in processing of toned milk is ₹ 27.15. Its manufacturing cost worked out to be $₹ 9.46 \mathrm{I}^{-1}$ with maximum on raw material $(91.12 \%)$ and the actual selling price of $₹ 35 \mathrm{I}^{-1}$, so the profit in this process is ₹ 25.54 (Table 8 and Figure 2). profit margin in manufacturing of different milk products, 2015-16

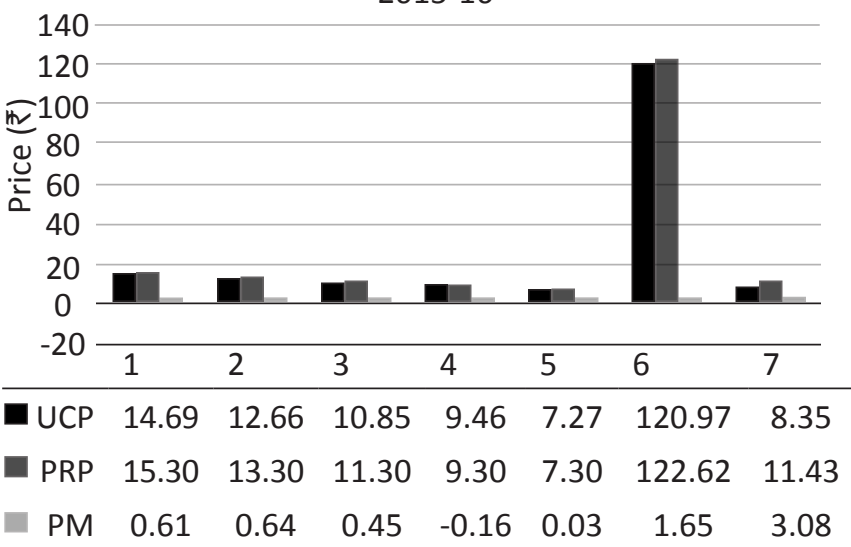

UCP: Unit cost of by plant; PRP: Price received of the plant; PM: Profit margin; 1: Full cream milk $\left(\mathrm{F}^{-1}\right)$; 2 : Standardized milk; 3: Toned milk; 4: Double toned milk; 5: Skimmed milk; 6: Ghee; 7: Ice-cream

Figure 1: Profit margins in manufacturing of different dairy products, 2015-16

\begin{tabular}{lccc}
\hline \multicolumn{4}{l}{ Table 8: Increasing milk production in India } \\
\hline Year & Production $(\mathrm{mt})$ & Year & Production $(\mathrm{mt})$ \\
\hline $1951-55$ & 17.0 & $1986-90$ & 63.8 \\
$1956-60$ & 19.0 & $1991-95$ & 78.3 \\
$1961-65$ & 20.0 & $1996-00$ & 80.6 \\
$1966-70$ & 21.2 & $2001-05$ & 97.1 \\
$1971-75$ & 23.2 & $2006-10$ & 110.3 \\
$1976-80$ & 30.4 & $2011-15$ & 117.0 \\
$1981-85$ & 41.5 & $2016-17$ & 124.5 \\
\hline
\end{tabular}

Milk powder, 8\%

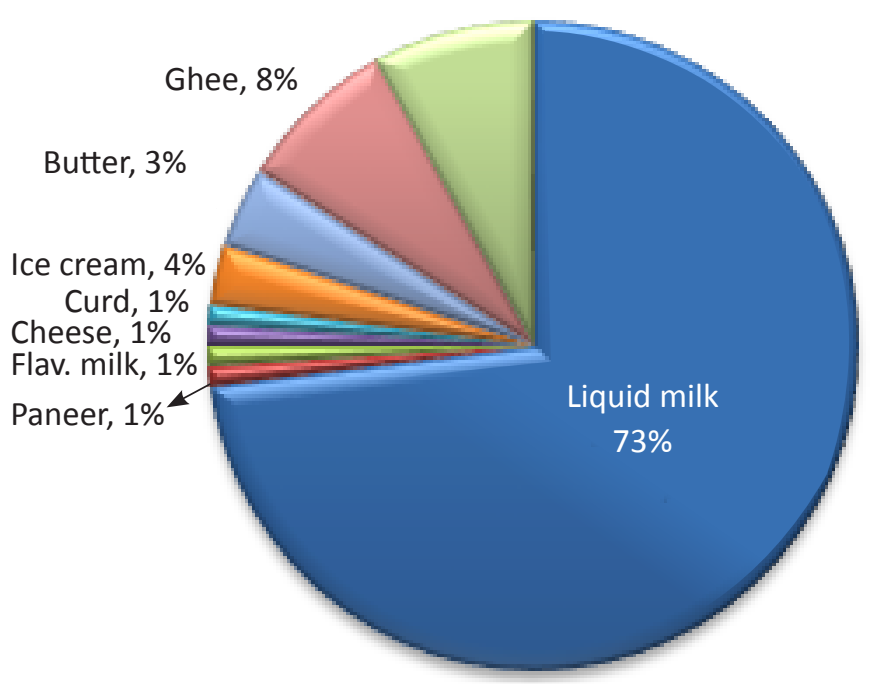

Figure 2: Market share of milk and milk product 


\section{Conclusion}

The comparison of unit manufacturing cost with price received by the plant for different products has shown that ice-cream manufacturing is the most profitable proposition. The standardization milk has been found most profitable among all types of milk pouches. The double toned milk has revealed a loss of $₹ 0.16 \mathrm{I}^{-1}$. Therefore, the study has suggested that the double toned milk should be raised at least to the break-even level to avoid losses in this product.

\section{References}

Anonymous, 2002. New Delhi; Department of Animal husbandry and Dairying, ministry of agriculture, Govt. of India.

Anonymous, 2017. Press information Bureau, ministry of agriculture Government of India.

Ahmed, T., 1997. Dairy plant engineering and management, $4^{\text {th }}$ Edition Allahabad; kitab mahal, 22-A, Sarp Jini Naidu Marg, 48-51.

Alganesh, T., 2002. Traditional milk and milk products handling practice and raw milk quality in Eastern Wollega, Ethiopia. M.Sc Thesis, Alemaya university, Ethiopia

Almaz, G., Howard, A.F., Wilhelm, H.H., 2001. Field survey and literature review on traditional fermented milk products of Ethiopia, int. J. Food microbial 68, 173-186.
Arbuckle, W.S., 1977. Ice cream, $3^{\text {rd }}$ edition, AVI Publishing Company, Inc. Westport Connecticut.

Bellion, J.C., 1988. Milk and Dairy products; Production and processing costs, FAO animal and health power 62, 23-24

Bourton, H., 1988. UHT processing of milk and milk products. ELSEVIER applied science Publisher Ltd. LONDON.

Dairy Handbook, 1980 Dairy and Food Engg. Division, AlfaLaval, Lund, Sweden.

Farrall, Arthur, W., 1963. Engg. For dairy and food products, $1^{\text {st }}$ edition Willey Eastern Private, New Delhi.

Glover, F.A., 1986. Modification to the composition of milk. Elsevier Applied Science Publisher, London.

Lewis, M.J., 1986. Advances in the heat treatment of milk. Elsevier Applied Science Publisher, London.

Padhi, P.K., 2014. Growth and development of Indian dairy sector-a progmatic analysis, Pacific Business Review International 7(4), 80-85.

Raju, G., Rama, M., 1980. Economic analysis of Processing of milk products at a milk products factory, vijaywada (AP), unpublished thesis at Kurukshetra University, Kurukshetra.

Shrivastava, M., Singh, J., 2008. "Dairy Development in New Millennium", Deep and Deep Publications, New Delhi. 